\title{
Businessmen Support Amidst the Turmoil: the Second Year of Bolsonaro's Presidency in Brazil
}

\author{
Apoyo de los empresarios en medio la agitación: el segundo año de la \\ presidencia de Bolsonaro en Brasil
}

\section{CAROLINA MOEHLECKE}

Fundação Getulio Vargas (FGV), Brazil

\begin{abstract}
The second year of Jair Bolsonaro's presidency in Brazil has been marked by multiple sources of pressure on the government. The COVID-19 pandemic has taken its toll on Brazilian lives, on the national health system and on the country's already sluggish economy. Hitting close to home, Bolsonaro has witnessed the beginning of several investigations against his also politician sons and increasing pledges for moderation from Centrão, the informal and yet powerful centrist coalition that has historically shaped Brazilian politics. Moreover, criticism from external markets and foreign powers regarding Brazil's mishandling of environmental policies has been constant, while Bolsonaro's campaign promises of economic liberalization remained largely unfulfilled. Quite puzzling though, domestic businessmen approval of the president increased over the year, as I show through the analyses of survey data. What explains this group's persistent support for Bolsonaro? This article reviews some of the main political events in Brazil in 2020 and it uses insights from International Political Economy and Brazilian politics scholarships to advance hypotheses that can explain why those who self-identify as businessmen remain steadfast supporters of the president, even amidst the economic, social, and sanitary turmoil in the country.
\end{abstract}

Keywords: Brazil, Bolsonaro, businessmen, economic elites, COVID-19.

\section{RESUMEN}

El segundo año de la presidencia de Jair Bolsonaro en Brasil ha estado marcado por múltiples fuentes de presión sobre el gobierno. La pandemia del virus COVID-19 ha hecho mella en las vidas de los brasileños, en el sistema nacional de salud y en la ya de por sí lenta economía del país. Pisándole los talones, Bolsonaro ha sido testigo del inicio de varias investigaciones judiciales contra sus hijos politicos y de crecientes promesas de moderación por parte del Centrão -la poderosa coalición centrista, si bien informal, que históricamente ha dado forma a la politica brasileña. Además, las críticas de los mercados externos y de las potencias extranjeras sobre el mal manejo de las politicas medioambientales por parte de Brasil han sido constantes, mientras que las promesas de campaña de Bolsonaro sobre la liberalización económica quedaron en gran medida incumplidas. Sin embargo, la aprobación del presidente por parte de los empresarios nacionales aumentó a lo largo del año, como muestro a través del análisis de los datos de las encuestas. ¿A qué se debe el persistente apoyo de este grupo a Bolsonaro? Este artículo revisa algunos de los principales acontecimientos políticos en Brasil en 2020 y utiliza ideas de la Economía Política Internacional y de la literatura de política brasileña para avanzar en las hipótesis que pueden explicar por qué aquellos que se autoidentifican como empresarios siguen siendo firmes partidarios del presidente, incluso en medio de la agitación económica, social y sanitaria en el país.

Palabras clave: Brasil, Bolsonaro, empresarios, élites económicas, COVID-19. 


\section{INTRODUCTION: A SNAPSHOT OF BRAZIL AND OF BOLSONARO'S PRESIDENCY IN 2020}

The year of 2020 in Brazil came to a close with nearly 200,000 victims from the COVID-19 virus (ARPEN 2021). This figure amounts to an excess of deaths of over $24 \%$ in comparison to 2019 (CONASS 2021). The country's GDP fell $4.1 \%$, less than what it was first projected, but still the largest contraction since 1996 (Barros 2021). Inflation has been rampant (4.52\%, the highest since 2016) and unemployment, high and persistent (13.5\%, the largest figure since 2012) (Barros 2021). This appalling economic scenario has been greatly due to the pandemic itself, which has sent shock waves around the world. However, the virus' consequences have been particularly harsh in Brazil, where a coordinated response from the federal government has been lacking since the very beginning.

On March $6^{\text {th }} 2020$, Bolsonaro addressed the nation for the first time regarding the COVID-19 situation. In a national TV and radio broadcast, the president urged Brazilians "not to panic" and to trust the government's actions. He also highlighted that the "cases started in China", which was in line with the administration's foreign policy of antagonizing with the Asian power. Following the World Health Organization's (WHO) classification of the COVID-19 situation as a global pandemic, Bolsonaro addressed the nation again on March $12^{\text {th }}$ and on March $24^{\text {th }}$. In the latter, the president reinforced that there was no reason to panic, and that the priority should be keeping jobs and "going back to normal". By then, several state and city authorities had put mobility restrictions in place. Bolsonaro suggested that the virus was only lethal to the elderly and to those with pre-existing health conditions: "In my particular case, due to my athlete's past, if I were to be contaminated by the virus, I wouldn't have to worry. I'd feel nothing. At most, I'd be hit by a little flu or a little cold (...)". In that occasion, Bolsonaro started to openly support the so-called "early treatment" with hydroxychloroquine, though no scientific evidence could support its efficacy. ${ }^{1}$

The March $24^{\text {th }}$ pronouncement set the tone for Bolsonaro's rhetoric regarding the pandemic throughout 2020. The president has repeatedly antagonized with governors and mayors by undermining local governments' efforts to restrict mobility to reduce the virus' spread. Backed by no evidence, he has questioned the safety and efficacy of the Chinese vaccine, Coronavac, whose supply has been negotiated by the governor of São Paulo, João Doria, an open defiant to Bolsonaro, with his own presidential aspirations for 2022. Finally, the president has kept promoting hydroxychloroquine and other so-called "early treatment" strategies, despite the ever-increasing amount of scientific studies showing that such treatments had no effect on preventing contamination nor on healing patients (Ghazy et al. 2020). As evidence of the erratic management of the pan-

Presidential pronouncements are available at: https://www.gov.br/planalto/pt-br/acompanhe-o- planalto/pronunciamentos/pronunciamentos-do-presidente-da-republica 
demic by the federal government, Brazil has had three different Health Ministers in 2020.

The combination of all these factors quickly put Brazil as one of the pandemic's epicenters. ${ }^{2}$ The president's rhetoric of prioritizing the economy over controlling the virus' spread was proved fallacious, as unemployment, inflation and the overall retreat of economic activities have been persistent. Partly elected because of his promises of liberalizing and modernizing the economy, the administration has delivered little in terms of much needed reforms. The Minister of Economy, Paulo Guedes (a PhD from the University of Chicago and proudly branded as a neoliberal), has been touted by the private sector as the key solution for the country's problems. In the 2018 campaign, Bolsonaro outsourced any questions from the press and from the electorate about the economy to Guedes. The then candidate often acknowledged that he did not know much about economics himself, but that he trusted Guedes to put the country in the right direction. However, except for the pensions' reform passed in 2019 (and which has been partly articulated during Michel Temer's term (2016-2018)), Guedes has not been able to effectively advance with his promises - partly because the president himself has not been seriously committed to those, partly because the Congress has skillfully modified several of the Executives' proposals towards their own preferences (Amorim Neto and Alves Pimenta 2020).

The governments' incapacity regarding the economy has pushed the deterioration of Brazil's public accounts. The country's gross debt reached $90 \%$ of GDP in 2020, an increase of 18\% relative to 2019 (Tesouro Nacional, 2021). The assessment that Brazil might not be able to reverse its dire economic situation and to balance its budget has caught the eye of foreign investors, as the country witnessed substantial foreign capital outflows in 2020. As usual in times of global crises when investors look for safer bets, all emerging economies have taken a hit. However, Brazil's performance has been worse than average (Schipani and Wheatley 2021).

One potential source for Brazil to reverse or at least attenuate the capital outflow trends could be green investment. Environmental, social and governance (ESG) investment has consolidated as a powerful force in international markets and is no longer a nearly utopic feature of global finance. ${ }^{3}$ As the home of the largest tropical forest in the world, Brazil is well-positioned to take advantage of these recent trends and to attract large sums of green investment. However, the administration has gone in the contrary direction and has severely weakened environmental protection in Brazil (Vale et al 2021). Such course of action has been strongly criticized by both the third and the private sectors, as well as by foreign powers.

At the time of this piece's writing, Brazil has surpassed 550,000 deaths from COVID-19 and vaccination rollout has been slow.

For instance, see Larry Fink's (CEO of BlackRock) letter to CEOs: https: / www.blackrock.com/corporate/ investor-relations / larry-fink-ceo-letter 
The poor management of the pandemic, the unfulfilled promises for improving the economy and the lost opportunity concerning green finance have all put the Bolsonaro administration under enormous pressure. Such pressure has been further increased by evidence that Bolsonaro's sons ${ }^{4}$ have been involved in different corruption schemes, which threatens his anti-corruption campaign rhetoric. These multiple sources of pressure have cornered Bolsonaro and reorganized domestic politics. The president had to let go of his promises to exert what he used to call "new politics" (never mind Jair had been a congressman himself for thirty years before running for presidency) and do what every president had to do in Brazil since the re-democratization: embrace Centrão, an informal and yet powerful center-right coalition whose ideology is fairly loose. Centrão does not push for programmatic politics, but rather focuses on negotiating support for the Executive's policies in exchange for positions in ministries and agencies. Historically, Centrão has supported both leftist and rightist administrations and is seen as the backbone of political stability in Brazil. In his 2018 campaign, Bolsonaro has attacked "old politics" that, in his view, were the fundamental cause of corruption in Brazil because of the type of pork-barrel relations it induced. However, as his performance in office failed to deliver a stronger economy and a more stable country, Bolsonaro got closer to Centrão and engaged in changes of ministries and heads of agencies.

As 2020 came to a close, Brazil found itself in an objectively difficult situation, but Bolsonaro's approval rates, if waning a bit, did not crumble. Even more remarkably, support from those who self-identify as businessmen has remained remarkably strong, relative to other socio- demographic groups. What explains this phenomenon? This piece examines microdata on Bolsonaro's approval over 2020 and shows that the group that self-identifies as businessmen displays persistent higher approval rates for Bolsonaro's presidency, in comparison with groups that have other occupations. Businessmen support as a predictor of high approval of Bolsonaro remains substantially important and statistically significant in the presence of several covariates such as income, education, age, and gender. To make sense of these patterns, I use insights from the International Political Economy and Brazilian politics scholarships and propose potential explanations that can be further assessed in future work. Throughout the paper, I connect both the empirical evidence and insights from the literature to some of the most relevant events of Brazilian politics in 2020, namely the pandemic mismanagement by the Executive, its vacillating economic policy, and its much criticized environmental and foreign policies. The last section concludes with lessons learned and prospects for the next two years of Bolsonaros' government. city of Rio. 


\section{BOLSONARO'S APPROVAL IN 2020: DO BUSINESSMEN AND NON-BUSINESSMEN DIFFER IN THEIR VIEWS?}

As just discussed, 2020 has been a rough year for the Brazilian sanitary, social, and economic outlooks. Based on well-established theories of economic voting (Valdini and Lewis-Beck 2018; Campello and Zucco 2020), we would expect a decline in the president's approval in the period. However, this is not what we observe. As shown by Figure 1, which was elaborated by Zucco and Campello (2021) and aggregates data from 195 public opinion polls, Bolsonaro's approval has increased in the second half of 2020.

Figure 1. Bolsonaro's approval across time.

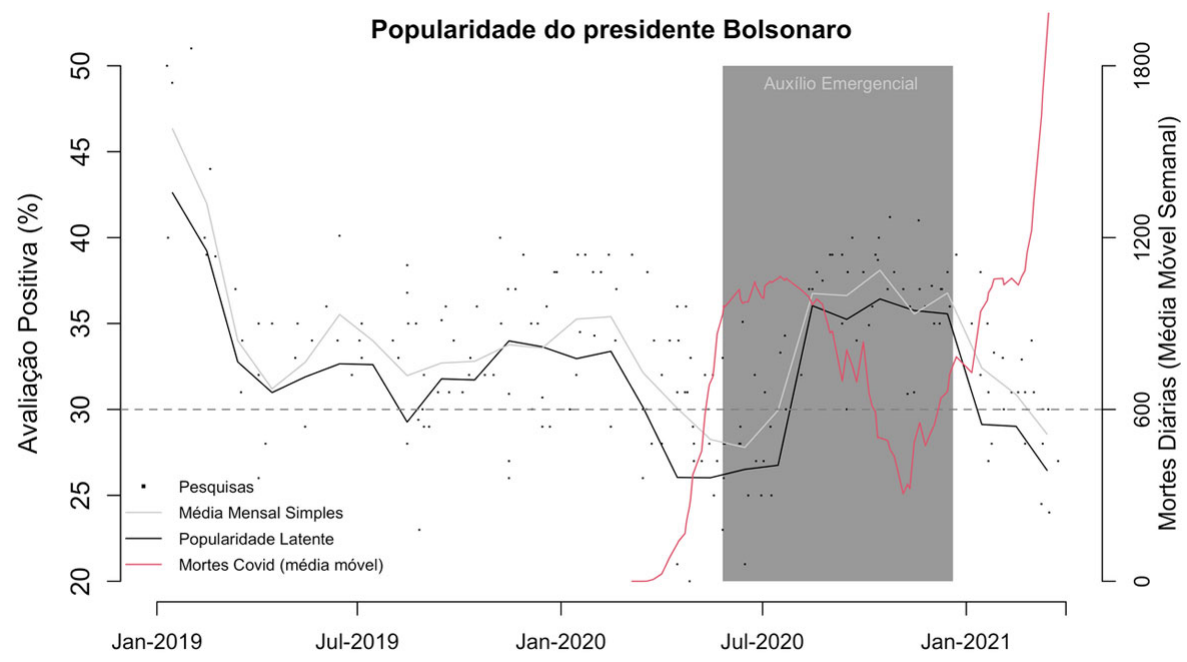

Note: Approval data (light gray line) comes from the aggregation of 195 opinion polls, represented by the black dots. The black line represents latent popularity, and the red line plots the moving average of deaths by COVID-19 in Brazil. The shaded area represents the period an emergency income aid program was in place in the country, an issue I discuss further in the paper. Graph is by Zucco and Campello (2021).

With the goal of unpacking these aggregated trends, I examine microdata on president's approval throughout 2020 as collected by Datafolha, one of the most prestigious polling institutes in Brazil. These microdata have been made available by the Public Opinion Studies Center (CESOP) at the University of Campinas (UNICAMP). ${ }^{5}$ The main goal of my analysis is to test the null hypothesis that support from businessmen does not differ from the general population's. Crucially, I consider self-identified occupation independently of income, which allows me to disentangle the effects of income from the effects of belonging to a particular group in society. If the null hypothesis is rejected and I find that ap- 
proval rates for the self-identified businessmen and the general population are indeed different, even in the presence of income controls, then we could infer that there is something distinctive about self-identifying as a businessman that shape individual political preferences. To be clear, the argument is not that businessmen have directly sustained Bolsonaro's high approval rates throughout 2020 alone - as I discuss further below, self-identified businessmen make up for roughly $5.5 \%$ of the analyzed sample. Notwithstanding, I am interested in providing a more systematic analysis of the phenomenon that is the steadfast support of a specific - and at least in principle, influential - group for the president.

Throughout 2020, Datafolha conducted eight waves of public opinion surveys whose focus was the pandemic. The surveys contained questions about Bolsonaro's management of the COVID-19 situation and about his overall performance in office. The two questions below make up the dependent variables in my analysis:

(DV 1): How do you assess President Jair Bolsonaro's performance regarding the coronavirus outbreak? Great/Good/Regular/Bad/Terrible

(DV 2): President Jair Bolsonaro has completed a year and X months in office. In your opinion, is Jair Bolsonaro doing a great/good/regular/bad/terrible job?

As for the main explanatory variable, I employ individuals' responses to Datafolha's question about occupation. Specifically, respondents are asked the following:

(IV): Are you currently working? If so, what is your main occupation? Formal wage earner/Informal wage earner/Public employee/Autonomous worker/Autonomous worker with a college degree/Businessmen/Free lancer/Rentier/Intern/Student/Housewife/Retired/Others/Unemployed

I recode responses to this question by separating the businessmen category from all the others. That is, I aggregate all the occupation categories except for businessmen. I recall that respondents provide this information based on how they self-identify their occupation.

I start the analysis by visually inspecting the president's approval rates among businessmen versus the aggregate of the other occupations. Figure 2 displays such rates regarding respondents' opinion on Bolsonaro's management of the pandemic.

Figure 2 indicates that those who self-identify as businessmen hold a quite different opinion regarding Bolsonaro's management of the pandemic relative to other groups of occupations. Businessmen are much more likely to evaluate the president's performance as "Great" and less likely to assess it as "Terrible". Interestingly, the positive perception of businessmen regarding Bolsonaro's management of the pandemic improves as time goes by and it does not always accompany the variation in the general population's re- 
Figure 2. Businessmen versus Other occupations' evaluation of president Jair Bolsonaro regarding the management of the COVID-19 pandemic.

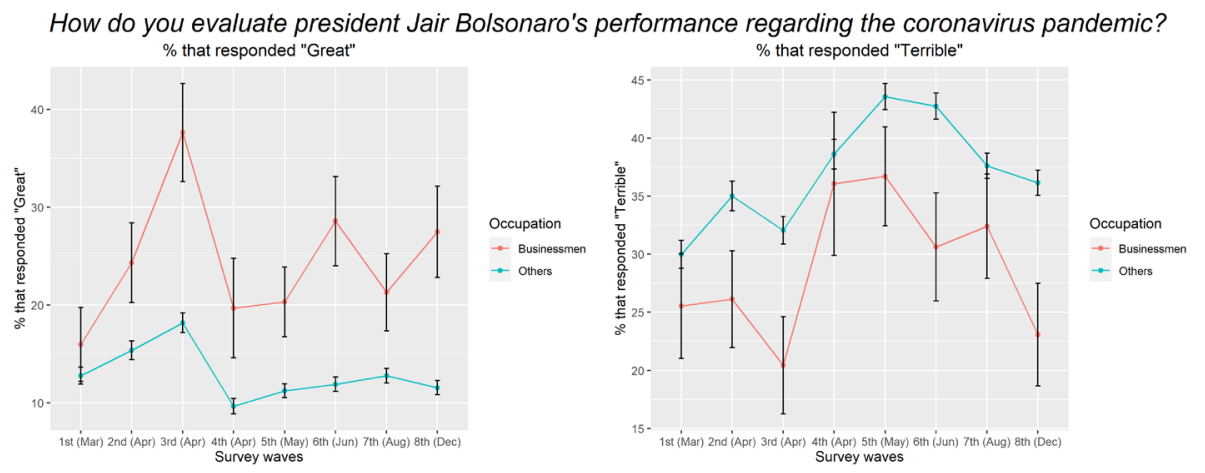

Note: Graphs have been elaborated by the author using data from Datafolha.

sponses. Importantly, the differences in opinion between the businessmen group and the other occupations group are statistically significant in the third (April), sixth (June), seventh (August) and eighth (December) survey waves, as shown by the results of Fisher's exact tests that yield p-values $<0.05$ and $<0.001$. The graph further corroborates this: even when standard errors are large due to the small sample of businessmen, the differences in approval rates between the two groups are easily distinguishable. This suggests that as the COVID-19 situation gets worse in Brazil (which reaches its peak between June and August, and so between the 6th and the 7th survey waves), businessmen's views become particularly detached from the overall population's. The relative improvement in the number of cases and deaths between the months of September and December is not sufficient to improve the overall population's opinion. However, this period is associated with a further enhancement of businessmen's regard for the president's management of the pandemic.

Figure 3 looks at respondents' approval of Bolsonaro's government in general. Again, the differences between businessmen and the population who has other occupations are rather striking, despite the large standard errors in some of the survey waves.

The visual inspection of approval rates is informative, but not conclusive. In order to assess whether self-identifying as a businessman is indeed an important factor associated with higher approval of the president at the individual-level (be it regarding the pandemic management or the government in general), I estimate four ordered logit models. In the first two models, the dependent variable is the ordered response to Datafolha's question about Bolsonaro's management of the pandemic, and it ranges from 1 (terrible) to 5 (great). I treat "don't knows" as a separate category (0). The first model uses data from the first survey wave (collected in March), while the second model employs data from the eight and 
Figure 3. Businessmen versus Other occupations' evaluation of president Jair Bolsonaro's government in general.

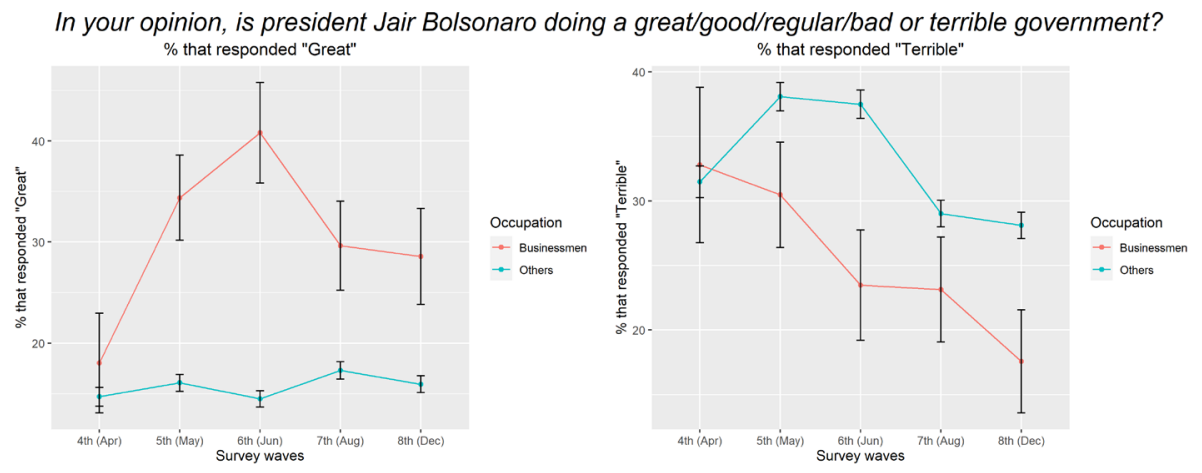

Note: Graphs have been elaborated by the author using data from Datafolha.

last wave (collected in December). ${ }^{6}$ The other two models employ the ordered responses to Datafolha's question about Bolsonaro's government in general as the dependent variable. I again estimate a model for the first survey wave that asks this question (the fourth one, collected in April) and for the last wave to do so (the eighth one, collected in December). The purpose of these models is to analyze, at the individual level, the effects of different respondents' characteristics on the probability of assessing the president's performance as either more positively or negatively and evaluate whether there are any changes between two points in time (the beginning and the end of the year).

The main independent variable in all four models is a dummy variable that attributes " 1 " to "businessmen" and " 0 " to other occupations. I estimate the models in the presence of controls for gender, age, income, and education. Ideally, I would like to include a variable for individuals' ideology, but Datafolha does not ask this question. The alternative for this would be a question on individuals' partisanship, but this is not an informative attribute of citizens' ideology in Brazil, as most people report they are not identified with a party (as a matter of fact, about $75 \%$ of respondents to Datafolha's surveys indicate they do not have a party).

Because interpretation of ordered logit models' coefficients is not straightforward, I report results graphically. ${ }^{7}$ Figure 4 shows the effect of the independent variable "Occupation", which has a value of " 1 " for businessmen and " 0 " otherwise on the probability of evaluating Bolsonaro's performance regarding the COVID-19 pandemic management as great/good/regular/bad/terrible, while holding the covariates (gender, income, education and age) constant at their means. 
The graphs clearly indicate a positive effect of self-identifying as a businessman in having a positive opinion of the president's management of the pandemic. The effects are larger in the December survey wave, so after the most difficult months of the pandemic in Brazil and right when the number of cases and deaths had experienced a decrease. The effect of self-identifying as a businessman is not statistically significant in the model that employs data from March $(\mathrm{p}$-value $=0.076)$, but it is in the model for December (p-value $<0.001)$.

Figure 4 . The effect of the dummy variable businessmen $=1$ on the probability of evaluating Bolsonaro's performance regarding the COVID-19 pandemic as great/good/regular/bad/terrible.

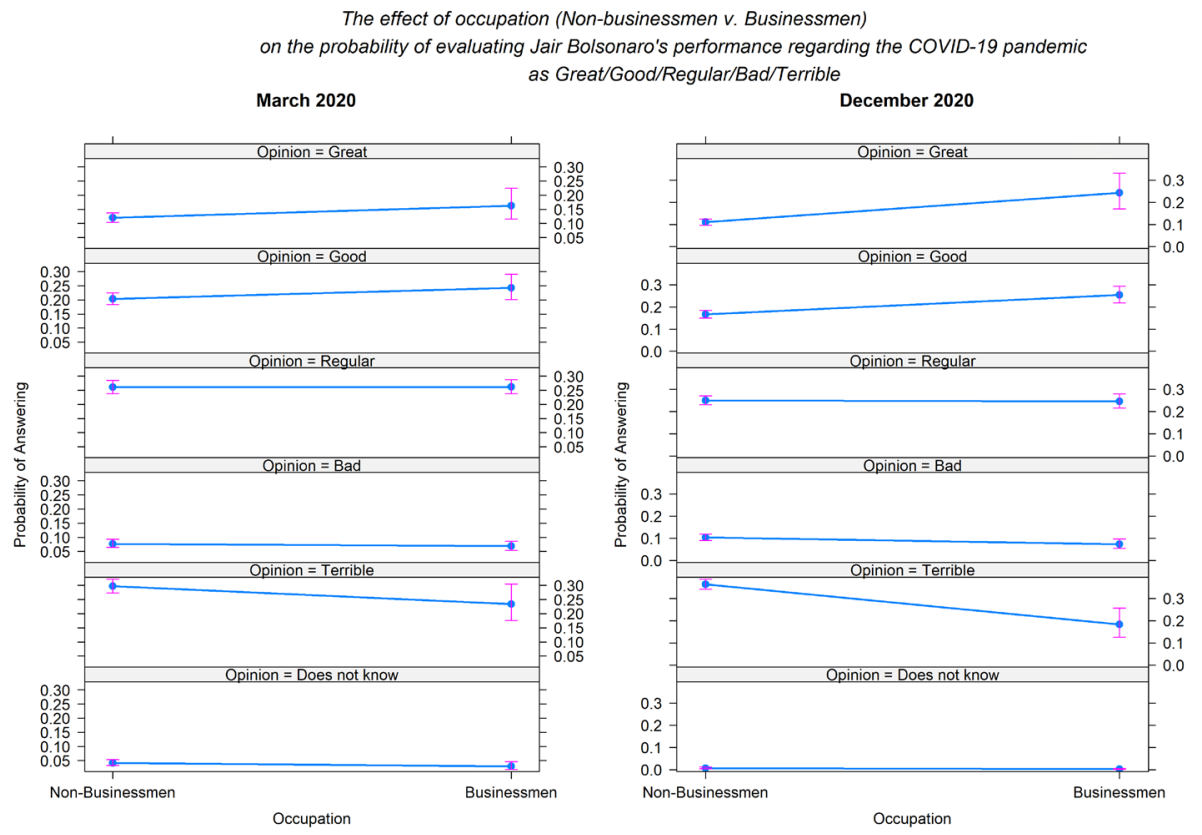

Note: All other covariates are held at their means. Graphs have been elaborated by the author using data from Datafolha.

To add to the evidence that the gap in opinion between businessmen and non-businessmen is substantively important, Figure 5 depicts the effect of being a businessman on the probability of evaluating Bolsonaro's overall performance in office as great/good/regular/bad/terrible. Again, covariates (gender, income, education, and age) are held constant at their means.

Once more, results indicate that those who self-identify as businessmen improved their assessment on Bolsonaro's government in general as time went by. While in April of 2020 the differences in opinion between businessmen and other occupations were neither substantively important nor statistically signif- 
icance $(p$-value $=0.789)$, the disparity between groups is striking in December. The coefficient on "businessmen $=1$ " is highly statistically significant ( $p$-value $<0.001$ ). The finding that self-identifying as a businessman is associated with a positive and statistically significant effect on Bolsonaro's approval in different scenarios and while controlling for relevant indicators such as income, education, gender and age suggests that there is something distinctive about belonging and self-identifying with this occupation group.

Figure 5. The effect of dummy variable Businessmen $=1$ on the probability of evaluating Bolsonaro's government in general as great/good/regular/bad/ terrible.
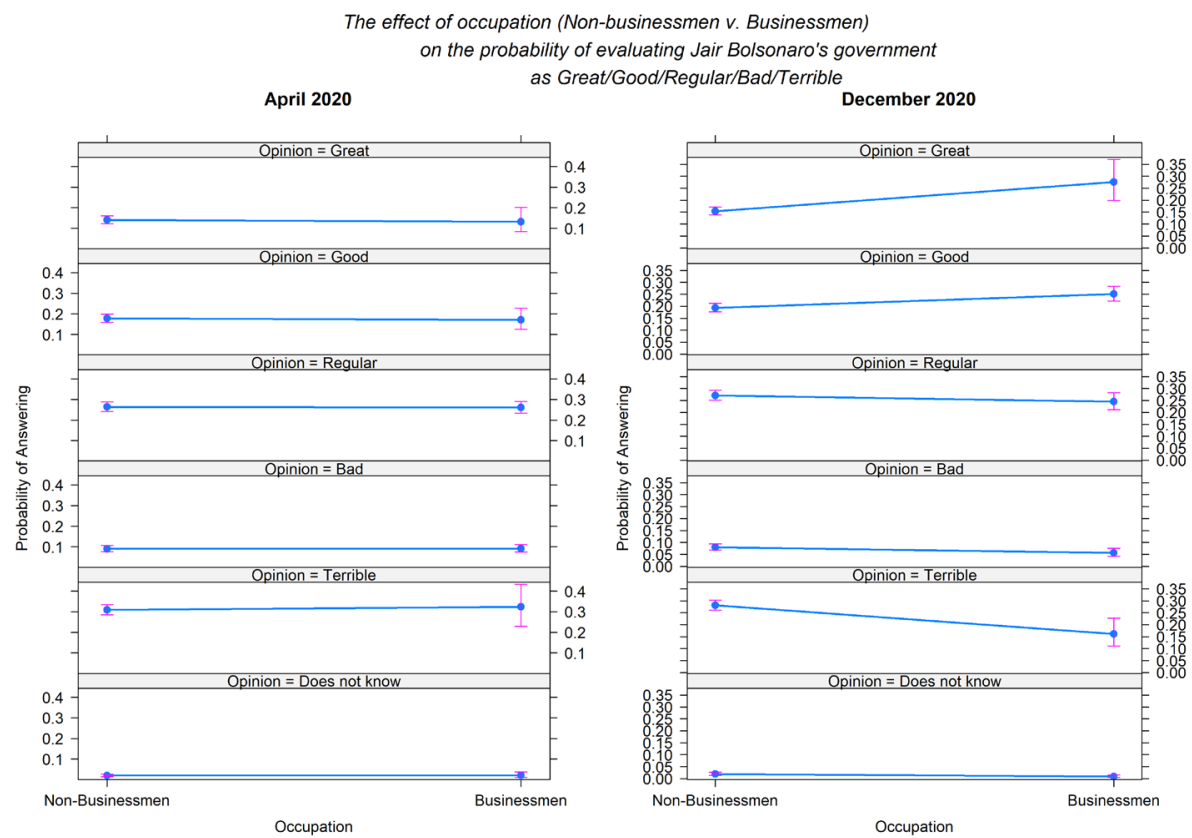

Note: All other covariates are held at their means. Graphs have been elaborated by the author using data from Datafolha.

\section{THE EFFECTS OF THE EMERGENCY AID INCOME PROGRAM IN THE PRESIDENT'S APPROVAL}

Now, one possible explanation for businessmen's support for the president might be associated with the emergency income aid disbursed by the government between April and November. The first five installments were of BRL 600 (the equivalent to roughly $60 \%$ of one minimum wage) and the three last ones were half that value. The aid program was targeted at informal workers, those out of jobs and at micro entrepreneurs, a category of self-employed 
people who run micro businesses whose total gross operating revenue cannot surpass BRL 81,000 per year. Those whose family income surpass either BRL 3,135 in total or BRL 522.50 per capita were not eligible to the assistance program.

Even though the emergency income aid program was a Congress's initiative and that Bolsonaro resisted its implementation and even opposed proposals to extend and enlarge its coverage, it is very possible that individuals attributed the initiative to the president (see, for instance, Santos and Ventura (2020) and Zucco and Campello (2021)). As a matter of fact, the gap between the population preferences and the president's has been the narrowest precisely in the period when the aid program was launched (Veiga 2021), which supports the idea that the public approved the initiative. Relatedly, it is possible that the businessmen category employed in this analysis is disproportionately comprised by micro entrepreneurs who received government assistance and that this explains the increasing approval rates of the president among this group. One way to assess this is to check how many individuals that self-identify as businessmen qualified for assistance. ${ }^{8}$ A cross-tabulation of income and occupation employing data from the first and the eighth survey waves indicates that very few people who self-identify as businessmen were eligible to emergency income aid - roughly $14 \%$. In the general population, the percentage of eligible individuals varies between $60 \%$ (first wave) to $80 \%$ (last wave).

We can also examine the effect of asking for and the effect of receiving emergency income aid directly, as Datafolha included such questions from the 5th survey wave onwards. To test this, I re-run the previously discussed models now including predictors that inform whether individuals asked for and/or received aid. I do so for all the waves that include questions pertaining the aid program, so the fifth (May), sixth (June), seventh (August) and eighth (December) surveys. As shown by Table 1, in the models that include the predictor "Did you ask for emergency income aid?", the effects of this variable are only meaningful and statistically significant in May. ${ }^{9}$ Interestingly though, self-identifying as a businessmen remains a positive and statistically significant variable in explaining higher approval rates for the president, both regarding his management of the pandemic and his government in general. That is, the attitude of applying to receive the emergency income aid does not topple the effect of self-identifying as a businessman.

Brazil has over 11 million registered microentrepreneurs, often people from lower income strata.

Full regression results, available upon request, also show a meaningful and statistically result in August. 
Table 1: Results from ordered logit models that verify the effect of asking for COVID-19's emergency income aid and of occupation on Bolsonaro's approval concerning both the management of the pandemic and his government in general.

\begin{tabular}{lcccc}
\hline & \multicolumn{3}{c}{ Dependent variable: Approval of } \\
\hline & COVID-19 Man. & Covid 19 Man. & Government & Government \\
\hline Businessman & $0.280^{* *}$ & $0.666^{* * *}$ & $0.465^{* * *}$ & $0.506^{* * *}$ \\
Male & $(0.127)$ & $(0.162)$ & $(0.128)$ & $(0.159)$ \\
& $0.280^{* * *}$ & $0.314^{* * *}$ & $0.288^{* * *}$ & $0.308^{* * *}$ \\
Some elementary school & $(0.060)$ & $(0.062)$ & $(0.059)$ & $(0.062)$ \\
& $-0.831^{* * *}$ & $-0.722^{* * *}$ & $-0.657^{* * *}$ & $-0.666^{* * *}$ \\
Age & $(0.187)$ & $(0.188)$ & $(0.182)$ & $(0.187)$ \\
& 0.004 & 0.002 & 0.005 & 0.003 \\
Asked for aid & $(0.003)$ & $(0.003)$ & $(0.003)$ & $(0.003)$ \\
& $0.179^{* * *}$ & 0.025 & $0.124^{*}$ & 0.083 \\
Observations & $(0.069)$ & $(0.069)$ & $(0.067)$ & $(0.069)$ \\
\hline
\end{tabular}

Note: $* \mathrm{p}<0.1 ; * * \mathrm{p}<0.05 ; * * * \mathrm{p}<0.01$. Coefficients of variables pertaining income and most education level groups have been suppressed due to space but are available upon request. Crucially, coefficients associated with income groups are almost never statistically significant.

On another hand, when it comes to the predictor "Have you received at least one installment of the emergency income aid?", the effects are not statistically significant in the May and December waves, but they do absorb the effects of self-identifying as a businessman, rendering the occupation variable mostly statistically insignificant, as shown by Table 2 .

Table 2: Results from ordered logit models that verify the effect of receiving COVID19's emergency income aid and of occupation on Bolsonaro's approval concerning both the management of the pandemic and his government in general.

\begin{tabular}{lcccc}
\hline & \multicolumn{4}{c}{ Dependent variable: Approval of } \\
\hline & COVID-19 Man. & Covid 19 Man. & Government & Government \\
\hline Businessman & 0.137 & Dec & May & Dec \\
\multirow{3}{*}{ Male } & $(0.241)$ & 0.366 & $0.443^{*}$ & 0.121 \\
& $0.270^{* * *}$ & $0.278)$ & $(0.244)$ & $(0.281)$ \\
Some elementary school & $(0.096)$ & $(0.105)$ & $(0.095)$ & $(0.104)$ \\
\hline \multirow{3}{*}{ Age } & $-1.081^{* * *}$ & $-1.450^{* * *}$ & $-0.896^{* * *}$ & $-1.465^{* * *}$ \\
& $(0.355)$ & $(0.368)$ & $(0.346)$ & $(0.336)$ \\
Asked for aid & -0.003 & 0.005 & -0.003 & 0.004 \\
& $(0.005)$ & $(0.006)$ & $(0.005)$ & $(0.006)$ \\
Observations & -0.013 & 0.079 & 0.035 & 0.020 \\
& $(0.096)$ & $(0.127)$ & $(0.095)$ & $(0.123)$ \\
\hline
\end{tabular}

Note: $* \mathrm{p}<0.1 ; * * \mathrm{p}<0.05 ; * * * \mathrm{p}<0.01$. Coefficients of variables pertaining income and most education level groups have been suppressed due to space but are available upon request. Crucially, coefficients associated with income groups are almost never statistically significant. 
In a nutshell, both asking and receiving emergency income aid only has a statistically significant effect on the president's approval for a very brief period of time. It is unfortunate that we do not have survey waves for September, October and November, but the fact that the effects of the aid predictors are significant in August but not in December allows us for the cautious conclusion that the "aid effect" is, at best, fickle. ${ }^{10}$ It is also interesting that asking for aid does not absorb the effects of being a businessmen, while actually receiving it does turn the occupation variable statistically insignificant.

One way to make sense of these results is to think of voters' preferences and attitudes in terms of self-interest and of sociotropic concerns. Specifically, a persistent and irrevocable positive and significant effect of the aid predictors could endorse the idea that the multiplier effect of the aid program might have motivated individuals (and businessmen, in particular) to increase their support for the president. The aid program has had a strong aggregate effect in the economy and has effectively prevented GDP from collapsing (Sanches, Cardomingo and Carvalho 2020). Other analyses indicate that the program was even responsible for temporarily attenuating the staggering levels of extreme poverty in Brazil (Duque 2020). However, the results discussed in this section suggest that individuals increased their approval of the president only if they actually received aid themselves and for a very brief period of time. Unfortunately, this hypothesis cannot be effectively tested with available data, so I leave it for further research. Nonetheless, they suggest that businessmen support for Bolsonaro could be more durable than support by the emergency income aid beneficiaries and it does not seem to be attached to the economy performance or to the pandemic trajectory. This opens the possibility that businessmen's support for the president respond to more ideological preferences than to a pragmatic assessment of the country's situation. I turn to entertain these ideas in the next section.

\section{WHY ARE BUSINESSMEN SO SUPPORTIVE OF BOLSONARO? A FEW POSSIBILITIES}

The previous section demonstrated that those who self-identify as businessmen in Brazil differ sharply from the general population on their opinion on Jair Bolsonaro's presidency, both overall and specifically concerning the COVID-19 pandemic management. What explains such differences? In this section, I review important events in Brazilian politics in 2020 in light of literature that indicates that such divergences could be due to two main factors. First, it could be that businessmen's support for Bolsonaro is pragmatic and reflects their endorsement of a political and economic environment that is aligned with businessmen's (and with the economic elites', more generally) material interests.

10 This is line with the previously cited analysis by Santos and Ventura (2020). More work to understand the effects of the emergency aid income will be necessary to fully grasp its consequences. 
Second, it could be that businessmen have their ideational preferences satisfied by Bolsonaro and that this is enough to placate any negative perceptions this group might have concerning the negative political, social, economic, and sanitary indicators in the country. To be clear, I do not propose to solve this puzzle, but rather to articulate possibilities. Effectively determining the relative contribution of material and ideational factors in individuals' likelihood to support the president is a challenging task for future research.

From the material standpoint, reasons why businessmen's support for Bolsonaro could be lower abound but can be largely aggregated into two categories: the economy and environmental and foreign policy. First, Brazil's economic outlook is objectively worrisome. As noted in the introduction, public accounts have deteriorated, and this has been pressuring the government to adjust expenses and revenue through administrative and tax reforms. Foreign investors have noted these imbalances and have been pulling out money from the country at an impressive rate. We know that foreign investors reduce developing countries" "room to move" when it comes to fiscal policy (Mosley 2000; 2005; Rudra 2008), as they pay special attention to inflation, public deficit and government debt (Mosley 2003). We also know that in moments of global uncertainty, investors flock to safer assets such as U.S. Treasury Bills, and constrain developing countries' ability to attract capital, even democratic ones (Ballard-Rosa, Mosley and Wellhausen 2019).

Even considering that Brazil has shifted an important portion of its debt from foreign to domestic creditors and from foreign to local currency throughout the 2000s, maturities are now shorter (Harris 2021). This is particularly worrisome in the pandemic context, as high public spending is key to alleviate the COVID-19's effects and to put the country on the recovery track. ${ }^{11}$ As necessary as they are, such high spending levels pressure the country's ability to repay its short-maturity debt. Foreign investors seem well-aware of the dilemmas facing the Brazilian economy and are signaling that they have become increasingly unwilling to keep financing this spending spree. And although Brazil has introduced a spending cap in 2016 as a tool to precisely signal commitment to investors with fiscal control, trends on yields on Brazilian bonds and on credit default swaps are clear indicators of foreign investors' concerns about debt's sustainability. In other words, foreign investors want to see reforms and are getting fidgety about this administration's ability to deliver them. The persistent support by domestic businessmen does not follow foreign investors' benchmarks and thus might put into question the pragmatism of domestic players in assessing the president's performance in office.

In addition to dynamics in the financial markets, foreign direct investment (FDI), a longer- term form of capital, has experienced a downturn in Brazil. Several major multinational corporations (MNCs) have ceased operations in 
the Brazilian territory in 2020, such as Mercedez-Benz, Ford, Sony and Roche, just to name a few (Marchesan 2021). MNCs' decisions to leave Brazil have been partly due to a larger phenomenon of global value chains (GVCs) restructuring in face of the pandemic (Golgeci, Yildiz and Andersson 2020), but mentions to the high cost of operating a business in Brazil and to the overall weakening of the Brazilian markets have been frequent explanations provided by foreign businesses leaving the country. One would expect Brazilian businessmen to at least partially mirror foreign firms' concerns about the business environment in the country, but this is not what the analysis in the previous section shows. Of course, important dissonant voices exist, though they tended to remain mostly silent throughout 2020.

One pragmatic explanation for the disparity between domestic and foreign firms could refer to competition dynamics. By leaving the country, MNCs end up increasing the available labor force, which decreases costs for domestic firms. The outflow of foreign firms also reduces competition for Brazilian producers, who have already been partially shielded from imports due to the real's depreciated exchange rate. ${ }^{12}$ However, these expected dynamics might not conform well to reality, as domestic firms are often supportive of FDI liberalization (Bauerle Danzman 2020). Importantly, the firms that left the country belong to industries in which Brazil does not have any major national players (e.g., automakers). Finally, while domestic manufacturers might have been able to offer more affordable manufactured goods to Brazilian consumers relative to imported substitutes, many firms have been struggling with the high costs of imported intermediates. ${ }^{13}$ To sum up, the quite negative perception of foreign investors and MNCs regarding Brazil and the characteristics of the domestic industry put into question the hypothesis that support for the president by domestic economic elites stems primarily from positive assessments of the economy - with the caveat that some groups of domestic businesses could be seen as material winners in the current scenario.

Second, we would expect domestic businessmen to be at least partially concerned about Bolsonaro's environmental and foreign policy. Intense fires in the Amazon had already caught the world's eye in 2019 and the trend continued in 2020. According to NASA's Earth Observatory, sensors were able to detect 1.4 million thermal anomalies (also known as "hot spots") in southern Amazon in 2020, an increase over the 1.1 million ones recorded in 2019 (Voiland 2021). Bolsonaro and his Minister of the Environment, Ricardo Salles ${ }^{14}$, have argued that numbers like the ones provided by NASA were a lie and that Brazil's en-

12 Export-oriented producers are the big winners of a depreciated real, but these are concentrated in the commodities sectors and should not be numerous enough to dominate the statistics assessed in the previous section. Of course, hard evidence for this claim cannot be assessed at this point, as Datafolha's surveys do not allow for determining businessmen's dependence on the external market.

13 An example of these concerns is this note by the Federation of Industries in the State of Pernambuco: http:// fiepe.org.br/com-alta-do-dolar-e-escassez-de-materia-prima-industria-enfrenta-aumento-em-seus-custos-de-producao/

14 Salles resigned while this piece was under review, in June 2021. 
vironmental policy is an example to the world. Controlling deforestation and preventing fires in regions like the Amazon and the Pantanal are surely enormous and difficult tasks, but the evidence that the Bolsonaro administration has purposedly worked towards undermining environmental regulation is strong. Vale et al. (2021) find that 57 legislative acts weakening environmental protection have been passed during this administration, half of which were approved during the pandemic in 2020. These data are consistent with Salles' statement that the government should enjoy the pandemic as an opportunity to weaken environmental legislation as the media would be focused on covering the COVID-19 situation. This statement has been made public in a leaked video of a ministerial meeting conducted in April 2020 (Spring 2020).

If rollbacks on environmental protection are a positive signal to some of the president's constituencies, such as some smaller farmers who benefit from deforestation and fires to illegally take possession of land, several groups have openly criticized the administration's approach towards the environment. First, powerful representatives of the agriculture sector have been voicing their support to more sustainable business and have been working to promote the idea that environmental protection is in the interest of farmers. ${ }^{15}$ This is due to increasing pressures from both the civil society and foreign investors who have been actively considering sustainability as a key factor in their investment decisions. Environmental, social and governance (ESG) trends have recently gained momentum, with ESG investors strongly scrutinizing Brazil. In June 2020, twenty-nine international financial institutions signed on a letter to the Brazilian government calling for action on the environment. The letter threatened divestment from Brazilian companies and from country's bonds in case the government failed to reverse deforestation trends. ${ }^{16}$ This movement by financial institutions was accompanied by an announcement from European companies warning about a potential boycott on Brazilian products and asking their governments to pressure Brazil, who then signed on a letter addressed to the vice-president, Hamilton Mourão. ${ }^{17}$

But why would Brazilian businessmen be concerned about these developments? From a general perspective, a bad reputation among international investors means less investment in Brazil, a capital-scarce economy that has been already struggling to attract investment given its precarious fiscal situation, as previously discussed. And, more specifically, foreign economic actors' concerns about Brazil's environmental policy have already been proving to be a hurdle to the ratification of the EU-Mercosur trade deal. After twenty years of thorny negotiations, the two regional blocks agreed on a deal in 2019. Ratifica-

15 The webpage of the Brazilian Association on Agribusiness (ABAG) contains several statements and notes supporting sustainability as in the interest of the agricultural sector: https://abag.com.br/sustentabilidade- abag/

16 Link to the letter:https://www.storebrand.no/asset-management/nyheter/storebrand-med-klimakrav-til-brasil

17 Link to the zil-Open- letter_EN.pdf 
tion has been expected to be difficult since the very beginning, as protectionist pressures from the EU abound. In this context, concerns regarding the Brazilian environmental policy end up serving as a point of leverage to European countries to delay ratification, which is politically interesting given these countries' struggles to appease their own domestic farmers, one of the most blatant losers of a trade deal between European and South American countries. For instance, France has repeatedly alleged that its citizens do not want to buy products from countries that are not committed to addressing climate change and has declared that it would not ratify the EU-Mercosur deal unless Brazil curbs deforestation (Gonzalez 2021). To be clear, there is evidence that true fair traders (i.e., consumers that legitimately care about the social and environmental sustainability of the products they buy) exist (Ehrlich 2018), but there is also evidence that governments often use sustainability concerns as a cover to sustain their protectionist positions. The EU-Mercosur deal represents an enormous opportunity for the export-oriented industries in Brazil. The agreement is also posited to benefit domestic firms that will have access to cheaper and more abundant intermediate goods. Of course, there are potential losers among Brazilian industries, as in any trade deal -specifically, domestic manufacturers will have to dispute consumers with more competitive European goods (e.g., wine producers in Southern Brazil). Nonetheless, Bolsonaro's lack of commitment with environmental policy has clear costs for economic elites. More research on the distributional consequences of Bolsonaro's environmental policy across sectoral lines and on these various domestic groups' ability to organize and pressure for their most desired outcome should yield important insights.

Bolsonaro's disastrous environmental policy has certainly dominated Brazil's image abroad, but other events in the country's foreign policy have also drawn attention and could have motivated more scrutiny from domestic businessmen, at least in principle. The Brazilian Ministry of Foreign Affairs has been historically held in high regard by its peers and considered an example of professionalism in international politics. Such positive image has suffered a strong blow after Bolsonaro named Ernesto Araújo to head the Ministry. Since his appointment, Araújo has been the stronghold of Bolsonaro's most ideological ideas, as he has repeatedly praised Donald Trump, antagonized with China and European powers, and fed an "anti-globalism", "anti-left" and "anti- politically correct" rhetoric. Out of the extensive collection of Araújo's radicalisms, the offensive against China has been the most consequential for the Brazilian economy. Throughout the years, China has become Brazil's top export destination, as it is a key market for Brazil's soybeans, meat, and iron ore. And while it is true that Brazil has suffered large import shocks from China and that such shocks have shaped Brazilians' perceptions on the Asian power (Campello and Urdinez 2020), Brazil's economic growth has been more attached to China than ever.

Part of the domestic economic elites recognize China's relevance and have asked for caution and moderation from the Minister of Foreign Affairs 
(Berald 2020). Nonetheless, Bolsonaro's and Araújo's devotion to Donald Trump have helped to sustain the anti-China position to signal to the president's most ideological and loyal voters. Araújo has repeatedly referred to the COVID-19 virus as the "Chinese virus" or "Comunavirus", this last one an allusion to communism. Trump's defeat in November might have offered an opportunity to Brazil to return to its historically independent and pragmatic foreign policy, which means a less contentious bilateral relationship with China and a less subservient one with the United States (Stuenkel 2020). This possible shift should be beneficial to Brazilian economic elites, which makes this group's current relative ease with Araújo's policies even more bewildering. ${ }^{18}$

In conclusion, foreign investors' grim assessments of the Brazilian economy and the government's damaging environmental and foreign policies could have motivated businessmen to hold lower approval rates for Bolsonaro, if we were to consider only material factors. Of course, some of the aspects of the current economic scenario in Brazil have been objectively benefiting sectors of the economic elite. Most notably, the depreciated real has pushed exports and shielded domestic manufacturers from foreign competition, while low interest rates have enabled the financial and the construction sector to grow. However, currency depreciation has also increased costs for domestic producers and pressured inflation, and the country's shaky financial situation should force an increase in interest rates in the medium term. More notably, the president's negligence regarding the pandemic could have been a reason for lower support, as it has become blatantly clear that the return to normal economic activities is strictly dependent on a successful vaccination campaign, an initiative that has not found any leadership from Bolsonaro.

These puzzles suggest that businessmen's support for Bolsonaro cannot be fully explained by material factors only. Thus, I now turn to considering ideational, non-material factors that might keep this group - and the country's economic elite, in general - so loyal to the president.

\section{CAN BUSINESSMEN'S SUPPORT FOR BOLSONARO BE BASED ON IDEATIONAL FACTORS? AND DOES IT MATTER?}

The analyses I conducted in section 2 are obviously limited. Crucially, Datafolha does not collect any information on respondents' ideational and cultural preferences, which have been shown to be important in explaining Brazilian votes on Bolsonaro (do Amaral 2020; Tavares de Almeida and Guarnieri 2020). Specifically, it could be that conservatism (Renno 2020) correlates with self-identifying as businessmen, which would not be a surprise: Margalit and Shayo (2020) find that people who start investing in stocks "are shifted to the 
right on policy questions." Their results obtained through a field experiment in England indicate that an individual's interactions with the market shape its values and preferences and thus supports the premise that self-identifying as a businessman is likely to have an effect on individuals' political views. This idea is further sustained by Bonica (2016), who finds that corporate elites in the United States donate to electoral campaigns in accordance to their own personal ideological preferences, rather than on behalf of their firms. This is not to say that corporations do not try to influence the political process -obviously they do, but they do so mainly through corporate lobbying (de Figueiredo and Richter 2014). While lobbying has the goal to shape politics that are favorable to firms, campaign donations seem to be manifestations of economic elites' personal ideological preferences, which might be independent of their firms' interests (Li 2018). Thus, contemporary International Political Economy literature offers some insights into why businessmen remain steadfast supporters of Bolsonaro, even if their material interests are being harmed or not entirely fulfilled by the president's policies.

Another important issue to be considered is how Bolsonaro's ability to shape the informational environment has influenced his supporters' views on the pandemic (Batista Pereira and Nunes 2021), and even their behavior facing the virus (Ajzenman, Cavalcanti and Da Mata 2020). As noted in the introduction, the president has effectively polarized the issue, which also limits our ability to draw inferences about his approval based on surveys. If Bolsonaro's supporters are not worried about the pandemic, it should be expected that the event would not affect their levels of support. But my analysis shows that businessmen's approval of Bolsonaro is also high concerning his government in general, which as discussed, is not justified by economic performance.

Different strands of the literature indicate that the political preferences of businessmen (and of the economic elites in general) could respond to ideational, non-material factors. But why does this matter? As argued by Saunders (2022), the stakes for understanding the role of elites in policy are high. ${ }^{19}$ On one hand, conventional wisdom holds that elites are more rational and strategic than the general public, which confers to the former more access and influence. On the other hand, there is increasing evidence that elites also hold biases and that they might not be so different from the general public, after all. In a large meta-analysis aimed at addressing the potential elite-public gap, Kertzer (2020) finds that although elites and masses differ across several characteristics, they are often similar in their response to treatments associated with preferences and decision-making. Of course, there are important heterogeneous effects. For instance, Hafner- Burton et al. (2014) find that government and business elites are indeed more patient and more strategic reasoners. These traits are precisely what constitute "eliteness", a concept that entails individuals' domain-specific expertise

19 The author focuses her research on the role of elites in the making of foreign policy, but I extend her point to other policies as well. 
and experience (Hafner-Burton, Hughes and Victor 2013). According to these definitions, we could expect Brazilian businessmen to grasp the harsh reality of the country's sanitary, social, and economic conditions and update their priors regarding the president's performance. However, what we see is precisely the opposite: the non-businessmen public is the one whose opinion on the president declines as both the pandemic and the economic situation get worse. This reinforces the need for a more solid understanding of both the material and non-material factors that shape businessmen's and elites' political preferences.

\section{CONCLUSION}

This article has sought to examine approval rates for president Bolsonaro throughout 2020 in order to explore cleavages between the views of those who self-identify as businessmen and of the general population. The analysis of microdata on public opinion as collected by Datafolha indicates that respondents who self-identify as businessmen tend to hold more positive opinions on both how Bolsonaro has been managing the COVID-19 pandemic in Brazil and on his government in general. Descriptive statistics show that businessmen are much more likely to see Bolsonaro's performance in office as "Great" and much less likely to see it as "Terrible" relative to the general population. The fact that these differences are observed precisely on the extremes of possible answers offered to respondents (which include "great/good/regular/bad/terrible") indicates that businessmen's support for the president is quite strong. The estimation of ordered logit models indicates that self-identifying as businessmen has a positive and statistically significant effect on president's approval, in the presence of income, education, gender and age covariates. And while the analysis demonstrates that the introduction of the emergency income aid program in April does have a limited positive and statistically significant effect on president's approval as well, the predictor associated with self-identifying as a businessman remains meaningful in most of the estimated models.

In reviewing some of the most relevant events in Brazilian politics in 2020, I discussed reasons why businessmen's support for Bolsonaro could be lower if their assessment of the president was essentially based on material factors. Negligence in the management of the pandemic, the weak economic performance, and the low prospects for much-needed reforms, coupled with misguided environmental and foreign policies have caught the international community's eye, including of foreign investors and of multinational corporations. Therefore, there is not a shortage of reasons why domestic economic elites could have been less supportive of the president in 2020. Of course, Brazilian businessmen have always kept a close relationship with the government (Evans 1979). And many observers would highlight that businessmen tend to not openly oppose the government in office and just try to make the best out of the situation and to avoid political turmoil. However, the data analyzed in this paper is derived from an anonymous survey, which means that those respon- 
dents who have self-identified as businessmen are most likely speaking their minds. Therefore, we can be somewhat confident that economic elites' support for Bolsonaro as detected by the data reflects reality. Less certain is the idea that such support is due to material satisfaction with the governments' policies. As discussed, evidence from the specialized literature indicates that ideational factors matter and that elites in general can be highly ideological. Obviously, this paper cannot determine the relative weight of material and non-material factors in shaping businessmen's political preferences, but it does pave the way for future research that can better assess this.

Additionally, I make the caveat that businessmen's and economic elites' preferences are heterogenous, one aspect that this study cannot address. International Political Economy theories identify cleavages in the preferences of different industries and of different firms (Bearce 2003; Lake 2009; Kim and Osgood 2019) and heterogeneous political views among the Brazilian economic elite have been observed over time (Bresser-Pereira and Diniz 2009). As discussed, there are reasons why some groups of the economic elite might be benefiting of the current administration's economic policies from a material standpoint. Unfortunately, the available data does not allow for a deeper analysis of such heterogeneity, which I also leave as a topic for future research.

Despite the study's limitations, the result that those who self-identify as businessmen and comprise the country's economic elite are more supportive of Bolsonaro seems robust. Then, the question that follows is if this result matters at all. Ultimately, investigating "eliteness" and elites' preferences and behavior is at the core of concerns about political representation. Elites have more channels to influence policy than the general public. If elites hold greater expertise and experience, concerns about this asymmetry in access to politicians would not be necessarily a bad thing. But if elites' interests are different from the general populations' and even conflict with the latter without carrying the "benefit" of being more factual, then we are faced with the worrisome scenario where politics are captured by the ideology of those who have the most material means, access and prestige.

To conclude, in times of high political polarization, there is plenty of evidence that citizens tend to compromise democratic principles over their partisanship. As Graham and Svolik (2020) put it regarding the American context, "most voters are partisans first and democrats only second." This type of evidence coupled with indications that economic elites in Brazil might be highly ideological suggest that this group's support for Bolsonaro, a “classical Latin American populist" (Amorim Neto and Alves Pimenta 2020) might continue unimpeded, even in face of objective troublesome economic, social, and sanitary scenarios. The big question refers to whether there is a threshold that, if passed, would provoke a change in elites' views regarding Bolsonaro during his last two years in office. It seems that as of now, much of Bolsonaro's fate depends on who will run against him in 2022 and whether there will be candidates on the ticket that will stir up elites' most ideological preferences, especially former president Luiz Inácio Lula da Silva from the Worker's Party (PT). "Anti-PT" sentiment 
has been shown to be a strong predictor of voters' attitudes in Brazil, despite the little impact that partisanship has historically had on voter behavior in the country (Samuels and Zucco 2018). Better understanding of the interplay of material and non-material preferences of the economic elite in conjunction with institutional and structural factors will be key to explain the present and the future of Brazilian politics

\section{REFERENCES}

Ajzenman, Nicolás, Tiago Cavalcanti and Daniel Da Mata. 2020. “More Than Words: Leaders' Speech and Risky Behavior during a Pandemic.". Available at SSRN: https://ssrn. com/abstract $=3582908$ or http:/ / dx.doi.org/10.2139/ssrn.3582908

Amorim Neto, Octavio and Gabriel Alves Pimenta. 2020. "The First Year of Bolsonaro in Office: Same Old Story, Same Old Song?". Revista de Ciencia Política 40 (2): 187-213.

ARPEN. 2021. "Painel Registral". Retrieved on March 15, 2021 from https://transparencia. registrocivil.org.br/especial-covid.

Ballard-Rosa, Cameron, Layna Mosley and Rachel L. Wellhausen. 2019. "Contingent Advantage? Sovereign Borrowing, Democratic Institutions and Global Capital Cycles." British Journal of Political Science 51(1):353-373.

Barros, Alerrandre. 2021, 03 March. "PIB cresce 3,2\% no $4^{\circ}$ tri, mas fecha 2020 com queda de 4,1\%, a maior em 25 anos". Agência IBGE Notícias. Retrieved on March 15, 2021 from https: / agenciadenoticias.ibge.gov.br/agencia-noticias/2012-agencia-de-noticias / noticias /30166-pib-cresce-3-2-no-4-tri-mas-fecha-2020-com-queda-de-4-1-a-maiorem-25-anos

Batista Pereira, Frederico and Felipe Nunes. 2021. "Media Choice and the Polarization of Public Opinion About Covid-19 in Brazil." Revista Latinoamericana de Opinión Publica $-(-): 1-19$.

Bauerle Danzman, Sarah. 2020. "Foreign Direct Investment Policy, Domestic Firms, and Financial Constraints." Business and Politics 22(2):279-306.

Bearce, David H. 2003. "Societal Preferences, Partisan Agents, and Monetary Policy Outcomes." International Organization 57(2):373-410.

Beraldo, Paulo. 2020, 06 April. "Líderes do Agronegócio Pedem Cautela com Relação à China: 'Momento é de Pacificar'”. Estadão. Retrieved on March 30, 2021 from https://politica.estadao.com.br/noticias/geral,lideres-do-agronegocio-pedem-cautela-com-relacao-a-china-momento-e-de-pacificar,70003262368

Bonica, Adam. 2016. "Avenues of influence: On the political expenditures of corporations and their directors and executives." Business and Politics 18(4):367-394.

Bresser-Pereira, Luiz Carlos and Eli Diniz. 2009. "Empresariado industrial, democracia e poder político." Novos Estudos CEBRAP 1(84):83-99.

Campello, Daniela and Cesar Zucco. 2020. The Volatility Curse: Exogenous Shocks and Representation in Resource-Rich Democracies. Cambridge: Cambridge University Press.

Campello, Daniela and Francisco Urdinez. 2020. "Voter and Legislator Responses to Localized Trade Shocks from China in Brazil." Comparative Political Studies -(-):1-32.

CONASS. 2021. "Painel de Análise de Excesso de Mortalidade por Causas Naturais no Brasil". Retrieved on April 30, 2021 from https://www.conass.org.br/\%20indicadores-de-obitos-por-causas-naturais/.

de Figueiredo, John M. and Brian Kelleher Richter. 2014. "Advancing the Empirical Research on Lobbying." Annual Review of Political Science 17:163-185.

do Amaral, Oswaldo E. 2020. "The Victory of Jair Bolsonaro According to the Brazilian Electoral Study of 2018." Brazilian Political Science Review 1(14):1-13.

Duque, Daniel. 2020, 24 September. "Auxílio emergencial para de crescer em agosto, e pobreza cai de novo; com redução do benefício a partir de setembro, porém, pobreza e 
desigualdade devem aumentar". Blog do IBRE. Retrieved on March 30, 2021 from https://blogdoibre.fgv.br/posts/auxilio-emergencial-para-de-crescer-em-agosto-e-pobreza-cai-de-novo-com-reducao-do-beneficio

Ehrlich, Sean. 2018. The Politics of Fair Trade: Moving Beyond Free Trade and Protection. Cambridge: Cambridge University Press.

Evans, Peter B. 1979. Dependent Development: The Alliance of Multinational, State, and Local Capital in Brazil. New Jersey: Princeton University Press.

Ghazy, Ramy Mohamed, Abdallah Almaghraby, Ramy Shaaban, Ahmed Kamal, Hatem Beshir, Amr Moursi, Ahmed Ramadan and Sarah Hamed N. Taha. 2020. "A systematic review and meta-analysis on chloroquine and hydroxychloroquine as monotherapy or combined with azithromycin in COVID-19 treatment." Scientific Reports 10(1):1-18.

Golgeci, Ismail, Harun Emre Yildiz and Ulf R. Andersson. 2020. "The Rising Tensions Between Efficiency and Resilience in Global Value Chains in the Post-COVID-19 World." Transnational Corporations Journal 27(2).

Gonzalez, Jenny. 2021, 16 February. “European Public Roundly Rejects Brazil Trade Deal Unless Amazon Protected". Mongabay. Retrieved on March 30, 2021 from https://news. mongabay.com/2021/02/european-public-roundly-rejects-brazil-trade-deal-unless-amazon-protected/

Graham, Matthew H. and Milan W. Svolik. 2020. "Democracy in America? Partisanship, Polarization, and the Robustness of Support for Democracy in the United States." American Political Science Review 114(2):392-409.

Hafner-Burton, Emilie M, Brad L LeVeck, David G Victor and James H Fowler. 2014. “Decision Maker Preferences for International Legal Cooperation." International Organization 68(4):845- 876.

Hafner-Burton, Emilie M., D. Alex Hughes and David G. Victor. 2013. "The cognitive revolution and the political psychology of elite decision making." Perspectives on Politics 11(2):368-386.

Harris, Bryan. 2021, 28 January. “Brazil's Economic Dilemma: Public Debt Restraint or Sluggish Recovery". Financial Times. Retrieved on March 30, 2021 from https://www. ft.com/content/2ac188f9-cf8b-4dec-be87-81913f872dcd

Kertzer, Joshua D. 2020. "Re-Assessing Elite-Public Gaps in Political Behavior." American Journal of Political Science -(-):-. https://doi.org/10.1111/ajps.12583

Kim, In Song and Iain Osgood. 2019. "Firms in Trade and Trade Politics." Annual Review of Political Science 22(1):1-19.

Lake, David A. 2009. "Open economy politics: A critical review." Review of International Organizations 4(3): 219-244.

Li, Zhao. 2018. "How Internal Constraints Shape Interest Group Activities: Evidence from Access- Seeking PACs." American Political Science Review 112(4):1067-1082.

Marchesan, Ricardo. 2021, 15 January. "Empresas que Tiraram o Brasil dos Planos". UOL. Retrieved on March 30, 2021 from https://economia.uol.com.br/stories/empresas-que-tiraram-o-brasil-dos-planos/

Margalit, Yotam and Moses Shayo. 2020. "How Markets Shape Values and Political Preferences: A Field Experiment." American Journal of Political Science 00(0):1-20.

Mosley, Layna. 2000. "Room to Move: International Financial Markets and National Welfare States." International Organization 54(4):737-773.

Mosley, Layna. 2003. Global Capital and National Governments. New York: Cambridge University Press.

Mosley, Layna. 2005. "Globalisation and the State: Still Room to Move?" New Political Economy 10(3):355-362.

Renno, Lucio R. 2020. "The Bolsonaro Voter: Issue Positions and Vote Choice in the 2018 Brazilian Presidential Elections." Latin American Politics and Society 62(4):1-23.

Rudra, Nita. 2008. Globalization and the Race to the Bottom in Developing Countries: Who Really Gets Hurt? New York: Cambridge University Press. 
Samuels, David J and Cesar Zucco. 2018. Partisans, Antipartisans, and Nonpartisans: Voting Behavior in Brazil. Cambridge: Cambridge University Press.

Sanches, Marina, Matias Cardomingo and Laura Carvalho. 2020. “Nota de Política Econômica n 7- Quão mais fundo poderia ter sido esse poço? Analisando o efeito estabilizador do Auxílio Emergencial em 2020." Centro de Pesquisa em Macroeconomia das Desigualdades. Retrieved on March 30, 2021 from https:/ /madeusp.com.br/wp-content/ uploads/2021/02/NPE007_site.pdf

Santos, Fabiano and Tiago Ventura. 2020. "Auxílio Emergencial e Popularidade do Bolsonaro.". UOL. Retrieved on July 17, 2021 from https://noticias.uol.com.br/colunas/observatorio-das-eleicoes/2020/11/18/auxilio-emergencial-e-popularidade-do-bolsonaro.htm

Saunders, Elizabeth N. 2022. "Elites in the Making and Breaking of Foreign Policy." Annual Review of Political Science. Forthcoming.

Schipani, Andres and Wheatley, Jonathan. 2021, 02 June. Financial Times. Retrieved on March 30, 2021 from https://www.ft.com/ content/9872c27b-689d-4a8b-a1e7-58a1b0bb50e1

Spring, Jake. 2020, 22 May. "Brazil Minister Calls for Environmental Deregulation While Public Distracted by COVID". Reuters. Retrieved on March 30, 2021 from https:/ /www. reuters.com/article/us-brazil-politics-environment/brazil-minister-calls-for-environmental-deregulation-while-public-distracted-by-covid-idINKBN22Y30Y

Stuenkel, Oliver. 2020. "What Will the U.S. Election Mean for Brazil's Diplomacy?" Foreign Policy. Retrieved on July 17, 2021 from https://foreignpolicy.com/2020/10/31/u-selection-2020-stakes-brazil-bolsonaro-trump-biden-diplomacy-trade-climate-change/

Tavares de Almeida, Maria Hermínia and Fernando Henrique Guarnieri. 2020. “The Unlikely President: the Populist Captain and his Voters." Revista Euro Latinoamericana de Análises Social y Politico 1(1):139-159.

Tesouro Nacional. 2021. "Relatório Anual da Dívida (RAD)". Retrieved on March 15, 2021 from https://www.tesourotransparente.gov.br/publicacoes/relatorio-anual-da-divida-rad/2020/114

Valdini, Melody E. and Michael S. Lewis-Beck. 2018. "Economic Voting in Latin America: Rules and Responsibility." American Journal of Political Science 62(2):410-423.

Vale, Mariana M, Erika Berenguer, Marcio Argollo, De Menezes, Ernesto B Viveiros, De Castro, Ludmila Pugliese, De Siqueira and Rita De C. 2021. "The COVID-19 pandemic as an opportunity to weaken environmental protection in Brazil." Biological Conservation 255(108994).

Veiga, Luciana Fernandes. 2021. Cultura Política: Valores Democráticos, Preferências Políticas, Autoritarismo e Nova Direita. In Governo Bolsonaro: Retrocesso Democrático e Degradação Política, edited by Leonardo Avritzer, Fabio Kerche and Marjorie Marona. Belo Horizonte: Autêntica.

Voiland, Adam. 2021. "Fires Raged in the Amazon Again in 2021". NASA Earth Observatory. Retrieved on March 30, 2021 from https://earthobservatory.nasa.gov/images /147946/ fires-raged-in-the-amazon-again-in-2020.

Zucco, Cesar and Daniela Campello. 2021. "O Paradoxo do Coveiro.". Folha de São Paulo. Retrieved on July 17, 2021 from https://piaui.folha.uol.com.br/o-paradoxo-do-coveiro/

Received: April 22, 2021

Accepted: August 8, 2021

Carolina Moehlecke is an assistant professor at the FGV's School of International Relations in São Paulo, Brazil. She holds a PhD from the University of Texas at Austin.

E-mail: carolina.moehlecke@fgv.br 